\title{
Aktivitas Antioksidan Umbi Bawang dayak (Eleutherine palmifolia) pada Tikus Diabetes Induksi Aloxan Monohidrat Berpotensi Mencegah Komplikasi Pada Penyakit Diabetes Melitus
}

\author{
Febrinda $\mathrm{AE}^{1}$, , Astawan $\mathrm{M}^{2}$, Wresdiyati $\mathrm{T}^{3}$, Yuliana $\mathrm{ND}^{2}$, dan Ridwan $\mathrm{E}^{4}$ \\ 1. Program Studi Teknologi Hasil Perkebunan, Politeknik Pertanian Negeri \\ Samarinda, Kalimantan Timur \\ ${ }^{2}$. Departemen Ilmu dan Teknologi Pangan, Fakultas Teknologi Pertanian IPB, Bogor, \\ Jawa Barat \\ 3. Departemen Anatomi, Fisiologi, dan Farmakologi, Fakultas Kedokteran Hewan, \\ IPB, Bogor, Jawa Barat \\ 4. Pusat Teknologi Terapan Kesehatan dan Epidemiologi Klinis, Bogor, Jawa Barat \\ *Email : aefebrinda@yahoo.com
}

\begin{abstract}
Bawang dayak (Eleutherine palmifolia) is traditionally used to cure diabetes mellitus of Dayak tribes people lived in Kalimantan, Indonesia. This study was aimed to evaluate the potency of aqueous and ethanolic extracts of Eleutherine palmifolia to prevent diabetic complication due to its antioxidant activities in alloxan induced diabetic rats. Alloxan induced diabetic Sprague Dawley rats were treated with $100 \mathrm{mg} \mathrm{kg}^{-1}$ bw of aqueos and ethanolic extract of Eleutherine palmifolia bulbs while non diabetic ones were treated with the dose of $500 \mathrm{mg} \mathrm{kg}^{-1}$ for 28 days. The observation was conducted on catalase and superoxide dismutase activities in blood serum, and the level of malonaldehyde (MDA) in liver organ. Administration of aqueous and ethanolic extracts orally to diabetic rats for 28 days gave significantly higher SOD and catalase enzymes activities and significantly lower liver malonaldehyde level compare to untreated diabetic rats. This antioxidant activities data, together with antihyperglycemic and antidislipidemia activities that had been reported before shows the potency of bawang dayak extract to prevent diabetic complication in diabetic rats.
\end{abstract}

Keywords: antioxidant, diabetes complication, bawang dayak, Eleutherine palmifolia

\begin{abstract}
ABSTRAK
Bawang dayak (Eleutherine palmifolia) merupakan tanaman lokal Kalimantan yang telah lama digunakan dalam pengobatan tradisional oleh masyarakat suku Dayak. Penelitian ini bertujuan untuk mempelajari potensi ekstrak air dan ekstrak etanol umbi bawang dayak untuk mencegah komplikasi penyakit diabetes berdasarkan aktivitas antioksidannya pada tikus diabetes induksi aloksan. Tikus diabetes diberi perlakuan ekstrak air dan ekstrak etanol dengan dosis $100 \mathrm{mg} / \mathrm{kg} \mathrm{BB}$, sementara tikus non diabetes mendapatkan dosis yang lebih besar, yaitu $500 \mathrm{mg} / \mathrm{kg}$ BB. Pengamatan dilakukan terhadap aktivitas enzim katalase dan SOD pada serum tikus percobaan, dan terhadap kadar malonaldehid pada organ hati tikus percobaan. Pemberian ekstrak air dan ekstrak etanol melalui jalur oral selama 28 hari kepada tikus diabetes memperlihatkan aktivitas SOD dan katalase yang signifikan lebih tinggi, dan kadar malonaldehid hati yang signifikan lebih rendah dibandingkan dengan tikus diabetes yang tidak diberi perlakuan. Data-data aktivitas antioksidan ini, bersama
\end{abstract}


dengan data aktivitas antihiperglikemik dan data antidislipidemia yang telah dilaporkan sebelumnya memberi petunjuk potensi ekstrak bawang dayak untuk mencegah komplikasi penyakit diabetes pada tikus percobaan.

\section{PENDAHULUAN}

Jumlah penderita diabetes mellitus terus meningkat dari tahun ke-tahun. Menurut data International Diabetes Foundation (2012), Indonesia menduduki urutan ke-tujuh dalam jumlah penderita diabetes terbanyak di dunia dengan jumlah 7.6 juta jiwa. Sebagian besar konsekuensi dari penyakit ini merupakan akibat komplikasi makrovaskuler dan mikrovaskuler, seperti penyakit jantung koroner dan katarak. Kematian akibat penyakit jantung koroner pada populasi diabetes adalah 2 sampai 4 kali lebih besar (Bell 1994). Sejak akhir tahun 1980-an tujuan dari pengobatan pada pasien diabetes telah berevolusi dari mencegah kematian, menghilangkan gejala, menuju normalisasi kadar glukosa darah untuk mencegah terjadinya komplikasi. Banyak hasil penelitian yang memperlihatkan bahwa pengendalian glukosa darah yang ketat pada pasien diabetes melitus tipe 1 secara signifikan mengurangi komplikasi seperti retinopathy, nephropaty dan neuropathy. Pasienpasien tersebut pada jangka panjang juga memperlihatkan efek-efek yang menguntungkan pada makrovaskular dalam studi-studi epidemiologi komplikasi dan intervensi diabetes (FDA 2008).

Bawang dayak (Eleutherine palmifolia) merupakan tanaman khas Kalimantan. Air rebusan atau perasan umbi bawang dayak secara tradisional diyakini mempunyai berbagai khasiat, antara lain sebagai obat kanker payudara, darah tinggi (hipertensi), kencing manis (diabetes melitus), kolesterol, dan bisul (Sa'roni et al. 1987; Saptowalyono 2007; Galingging 2009). Potensi bawang dayak sebagai tanaman obat sangat besar namun kajian ilmiah mengenai khasiat umbi bawang dayak masih sangat sedikit. Penelitian ini bertujuan untuk membuktikan secara ilmiah khasiat antidiabetik dan antioksidan umbi bawang dayak serta mengkaji keamanan konsumsinya pada tikus percobaan agar dapat dimanfaatkan sebagai sumber pangan fungsional.

\section{METODE PENELITIAN}

\section{Ekstraksi Umbi Bawang Dayak}

Bahan tanaman yang digunakan adalah umbi bawang dayak (Eleutherine palmifolia) segar yang diperoleh dari Samarinda, Kalimantan Timur. Umbi bawang dayak segar dihancurkan menggunakan blender Philips dengan menambahkan pelarut (air dan etanol) dengan perbandingan 1:4 (b:v). Larutan direndam selama 30 menit di dalam sonikator GFL 1092. Kemudian larutan dikocok menggunakan shaker incubator Hitachi L200 pada suhu ruang selama dua jam. Kemudian larutan dipisahkan menggunakan sentrifus Eppendorf $5810 \mathrm{R}$ dan fase terlarut dikumpulkan untuk disaring menggunakan kertas saring Whatman no 1. Larutan ekstrak yang diperoleh selanjutnya dikeringkan menggunakan pengering beku hingga didapatkan ekstrak kering air dan ekstrak kering etanol.

\section{Tikus Percobaan}

Penelitian ini dilakukan sesuai dengan Guide for The Care And Use of Laboratory Animals (National Research Council 2011). Ijin etik untuk penelitian menggunakan hewan percobaan dikeluarkan oleh Komite Etik Kementerian Kesehatan Republik Indonesia. Tikus Sprague Dawley jantan berusia sekitar 8 minggu dengan berat 180 sampai $200 \mathrm{~g}$ didapatkan dari Badan Pengawasan Obat dan Makanan. Hewan dipelihara dengan kondisi 
standar laboratorium $\left(26{ }^{\circ} \mathrm{C}\right.$, siklus 12 jam terang/gelap) dan diberi makan dan minum secara ad libitum. Ransum standar yang digunakan mengacu pada AOAC 2005.

\section{Penentuan Dosis Percobaan}

Dosis percobaan untuk tikus diabetes ditentukan dengan melakukan uji toleransi glukosa oral (Etuk 2010) dan dosis untuk tikus sehat adalah lima kali lebih besar dari dosis untuk tikus diabetes. Sebanyak 55 ekor tikus sehat dibagi menjadi 11 kelompok. Sebanyak 5 kelompok menerima larutan ekstrak air dengan dosis 100, 200, 300, 400, dan $500 \mathrm{mg} \mathrm{kg}^{-}$ 1; 5 kelompok menerima larutan ekstrak etanol dengan dosis 100, 200, 300, 400, dan 500 mg kg-1; dan satu kelompok merupakan kelompok kontrol yang menerima 1 ml larutan akuades. Tikus dipuasakan semalam dan keesokan harinya dilakukan pengukuran glukosa darah. Kemudian diberikan larutan perlakuan dengan cara penyondean. Tiga puluh menit kemudian seluruh kelompok tikus mendapatkan penyondean larutan glukosa 50\% dengan dosis $2.5 \mathrm{~g} \mathrm{~kg}^{-1}$ bb dan diikuti dengan pengukuran glukosa darah setiap 30 menit selama dua jam. Dari data glukosa darah tersebut dapat dibuat kurva yang kemudian dihitung luas areanya. Dosis yang dipilih adalah kelompok dosis terendah yang memberikan luas area dibawah kurva signifikan lebih kecil dari kelompok kontrol.

\section{Rancangan Percobaan}

Tikus dibagi ke dalam 7 kelompok masing-masing terdiri atas 6 ekor. Kelompok 1 (KD) adalah tikus diabetes yang disonde dengan $1 \mathrm{ml}$ akuades dan berlaku sebagai kontrol positif, kelompok $2(\mathrm{KS})$ adalah tikus sehat yang disonde dengan $1 \mathrm{ml}$ akuades dan berlaku sebagai kontrol negatif, kelompok 3 (KO) adalah tikus diabetes yang disonde dengan obat glibenclamide dosis $10 \mathrm{mg} \mathrm{kg}^{-1}$ bb dan berlaku sebagai kontrol obat, kelompok 4 (DEA) adalah tikus diabetes yang disonde dengan ekstrak air umbi bawang dayak, kelompok 5 (DEE) adalah tikus diabetes yang disonde dengan ekstrak etanol umbi bawang dayak, kelompok 6 (SEA) adalah tikus sehat yang disonde dengan ekstrak air umbi bawang dayak, dan kelompok 7 (SEE) adalah tikus sehat yang disonde dengan ekstrak etanol umbi bawang dayak. Kondisi diabetes dibuat dengan injeksi peritoneal senyawa alloxan monohidrat yang dilarutkan dalam $\mathrm{NaCl}$ fisiologis dengan dosis $110 \mathrm{mg} \mathrm{kg}^{-1} \mathrm{bb}$. Tikus dianggap diabetes bila kadar glukosa darah setelah tiga hari dari penyuntikan menunjukkan nilai di atas $200 \mathrm{mg} \mathrm{dl}^{-1}$. Penyondean ekstrak umbi bawang dayak dan akuades dilakukan setiap hari pada pukul 08.00 sampai 09.00 WIB selama 28 hari. Semua kelompok diterminasi pada hari ke-29 dengan cara euthanasia menggunakan suntikan ketamine. Serum dan hati segera disimpan untuk dianalisis lebih lanjut.

\section{Prosedur Analisis}

Kadar malonaldehid (MDA) hati diukur menggunakan metode Singh (2002). Aktivitas enzim superoksida dismutase (SOD) serum diukur menggunakan metode Wijeratne et al. (2005). Aktivitas enzim katalase serum diukur menggunakan metode Sinha (1972).

\section{Pembuatan homogenat hati, (Huang et al. 2011)}

Sampel hati diiris dan segera dicuci dengan ice-cold saline untuk menghilangkan darah. Homogenat (10\% w/v) dipreparasi dalam buffer phosphat $50 \mathrm{mM}$ dingin $(\mathrm{pH} 7)$ dan menghasilkan suspensi yang disentrifus pada $1000 \mathrm{rpm}$ suhu $4{ }^{\circ} \mathrm{C}$ selama 10 menit. Supernatan jernih digunakan untuk penentuan kandungan malonaldehid (MDA). 


\section{Penentuan kandungan malonaldehid (Ohkawa et al. 1979)}

$1250 \mu \mathrm{l}$ sampel dicampurkan dengan $200 \mu \mathrm{l}$ SDS, $50 \mu \mathrm{l}$ EDTA dan $1500 \mu \mathrm{l}$ TBA. Setelah divorteks campuran ditambahkan $1500 \mu \mathrm{l}$ TCA. Selanjutnya disentrifus pada $10 \mathrm{G}$ selama 10 menit. Supernatan yang terbentuk diambil dan dimasukkan ke dalam tabung reaksi. Tabung ditutup dengan kelereng dan ditempatkan pada penangas air bersuhu $80^{\circ} \mathrm{C}$ selama 20 menit. Selanjutnya diukur absorbansinya pada panjang gelombang $532 \mathrm{~nm}$. Sebagai larutan standar berkadar 2.5 digunakan campuran $100 \mu$ tetrametoksipropan, 1150 $\mu \mathrm{l}$ akuades, $200 \mu \mathrm{l}$ SDS, $50 \mu \mathrm{l}$ EDTA dan $1500 \mu \mathrm{l}$ TBA. Sedangkan untuk larutan blanko digunakan campuran $1250 \mu \mathrm{l}$ akuades, $200 \mu \mathrm{l}$ SDS, $50 \mu \mathrm{l}$ EDTA, dan $1500 \mu \mathrm{l}$ TBA.

$$
\text { Kadar malonaldehid (TBARS) }\left(\frac{n m o l}{m l}\right)=\frac{A b s \text { uji-Abs blanko }}{\text { Abs std-Abs blanko }}[\text { Std }]
$$

\section{Penentuan aktivitas SOD (Wijeratne et al. 2005)}

Campuran reaksi terdiri dari $1 \mathrm{ml}$ hipoxantin $3 \mathrm{mM}, 1 \mathrm{ml}$ xantin oksidase $100 \mathrm{mIU}, 1 \mathrm{ml}$ diethylenetriaminepentaacetic acid $12 \mathrm{mM}, 1 \mathrm{ml}$ nitro blue tetrazolium $178 \mu \mathrm{M}$ dan $1 \mathrm{ml}$ serum. Semua larutan disiapkan dalam PBS. Absorbansi diukur pada menit ke 0 hingga 30 dengan interval 5 menit pada panjang gelombang $560 \mathrm{~nm}$. Aktivitas SOD diukur menggunakan rumus $[1-(A / B)] \times 100$, di mana A adalah absorbansi sampel pada menit ke-30 dan B adalah absorbansi blanko pada menit ke-30.

\section{Penentuan aktivitas katalase (Sinha 1972)}

Sampel sebanyak $1 \mathrm{ml}$ dicampurkan dengan $5 \mathrm{ml}$ bufer fosfat $0.05 \mathrm{M} \mathrm{pH} 7$ dan divorteks. Selanjutnya ditambahkan $4 \mathrm{ml} \mathrm{H}_{2} \mathrm{O}_{2} \quad 0.2 \mathrm{M}$ dan diinkubasi selama 30 detik. Larutan ini disebut larutan uji. Sebagai larutan standar adalah larutan $\mathrm{H}_{2} \mathrm{O}_{2}$ dengan konsentrasi 0 , $0.04,0.08,0.12,0.16,0.2$, dan 0.4M. Selanjutnya $1 \mathrm{ml}$ larutan uji dimasukkan ke dalam tabung reaksi dan ditambahkan dengan $2 \mathrm{ml} \mathrm{K}_{2} \mathrm{Cr}_{2} \mathrm{O}_{7} 5 \%$. Tabung dipanaskan pada air mendidih selama 10 menit. Setelah dingin absorbansinya dibaca pada panjang gelombang $570 \mathrm{~nm}$. Absorbansi yang terbaca setara dengan konsentrasi $\mathrm{H}_{2} \mathrm{O}_{2}$ yang tersisa. Jumlah $\mathrm{H}_{2} \mathrm{O}_{2}$ yang terpakai oleh katalase adalah $0.2 \mathrm{M}$ - konsentrasi $\mathrm{H}_{2} \mathrm{O}_{2}$ terbaca. 1 unit aktivitas katalase dinyatakan sebagai banyaknya $\mathrm{H}_{2} \mathrm{O}_{2}$ dalam mol yang digunakan oleh katalase tiap menit.

\section{Analisis Statistik}

Analisis statistik yang dilakukan adalah one way ANOVA yang diikuti uji lanjut DMRT menggunakan perangkat lunak XLSTAT. Nilai $\mathrm{P}<0.05$ dianggap sebagai signifikan secara statistik. Hasil analisis disajikan dalam bentuk tabel sebagai nilai rata-rata \pm standar deviasi.

\section{HASIL DAN PEMBAHASAN}

\section{Penentuan Dosis Percobaan}

Pemberian ekstrak air dan ekstrak etanol umbi bawang dayak berhasil menurunkan kadar glukosa darah setelah makan sebagaimana dibuktikan pada hasil uji toleransi glukosa oral yang disajikan pada Tabel 1. Berdasarkan uji tersebut juga dapat ditetapkan dosis eksperimen yang akan diberlakukan pada pengujian aktivitas in vivo. 
Tabel 1 Luas area di bawah kurva hasil uji toleransi glukosa oral ekstrak umbi bawang dayak pada tikus percobaan

\begin{tabular}{lcccccc}
\hline \multirow{2}{*}{$\begin{array}{c}\text { Umbi } \\
\text { bawang } \\
\text { Dayak }\end{array}$} & $\begin{array}{c}\mathbf{0} \\
\text { (kontrol) }\end{array}$ & $\mathbf{1 0 0}$ & $\mathbf{2 0 0}$ & $\mathbf{3 0 0}$ & $\mathbf{4 0 0}$ & $\mathbf{5 0 0}$ \\
\hline Ekstrak air & $6976 \pm$ & $4590 \pm$ & $5022 \pm$ & $3503 \pm$ & $4820 \pm$ & $4061 \pm$ \\
& $798 \mathrm{a}$ & $1423 \mathrm{~b}$ & $1330 \mathrm{ab}$ & $1100 \mathrm{~b}$ & $1338 \mathrm{~b}$ & $1929 \mathrm{~b}$ \\
Ekstrak & $6976 \pm$ & $3585 \pm$ & $4555 \pm$ & $3848 \pm$ & $4159 \pm$ & $4538 \pm$ \\
etanol & $798 \mathrm{a}$ & $1016 \mathrm{~b}$ & $825 \mathrm{~b}$ & $1200 \mathrm{~b}$ & $2364 \mathrm{~b}$ & $1854 \mathrm{~b}$ \\
\hline
\end{tabular}

Rerata dalam baris yang sama dengan notasi huruf berbeda menunjukkan signifikan pada taraf $\alpha 5 \%$.

Berdasarkan hasil tersebut terlihat bahwa dosis ekstrak terendah yang memberikan luas area di bawah kurva (AUC, area under curve) signifikan lebih kecil daripada kontrol adalah $100 \mathrm{mg} \mathrm{kg}^{-1}$ bb baik untuk ekstrak air ataupun ekstrak etanol. Dengan demikian dosis tersebut yang dipilih untuk diberikan pada tikus diabetes, dan untuk tikus normal diberikan dosis lima kali lebih besar yaitu $500 \mathrm{mg} \mathrm{kg}^{-1} \mathrm{bb}$.

\section{Kadar Malonaldehid, Aktivitas Enzim SOD dan Katalase Serum Tikus Percobaan}

Aktivitas enzim SOD dan katalase serum, serta kadar malonaldehid hati setelah 28 hari percobaan disajikan pada Tabel 2. Nilai MDA hati kelompok KD signifikan lebih tinggi dibandingkan kelompok lain. Meskipun nilai MDA kelompok DEA, DEE dan KO lebih rendah daripada $\mathrm{KD}$, namun nilai tersebut secara signifikan masih lebih tinggi dari kelompok KS. Demikian pula kelompok SEE terlihat mempunyai nilai MDA yang signifikan lebih tinggi dibandingkan KS dan SEA. Aktivitas SOD dan katalase serum pada kelompok DEA dan DEE signifikan lebih tinggi dari KD, bahkan tidak berbeda signifikan dengan kelompok KS. Kelompok KO memiliki nilai aktivitas SOD yang juga tidak berbeda signifikan dengan kelompok KS, namun aktivitas katalasenya lebih rendah daripada yang dimiliki oleh kelompok KS, DEA dan DEE.

Senyawa malonaldehid (MDA) merupakan indeks peroksidasi lipid. Peningkatan lipid peroksidasi pada tikus diabetes adalah akibat menguatnya produksi Radical Oxygen Species (Kumar et al. 2010). Ekstrak air dan etanol umbi bawang dayak mampu mengurangi terjadinya peroksidasi lipid yang dibuktikan dengan nilai MDA hati yang lebih rendah dibandingkan pada tikus kontrol positif. Kemampuan ekstrak umbi bawang dayak dalam mencegah peroksidasi lipid melalui kerja antioksidan ditunjukkan pula dengan meningkatnya aktivitas katalase dan SOD serum pada tikus diabetes yang diberi ekstrak air dan etanol. Kemampuan antioksidan umbi bawang dayak juga dibuktikan pada kelompok tikus non diabetes, di mana antioksidan yang dimiliki ekstrak tanaman tersebut mampu menghemat pemakaian antioksidan alami yang ada di dalam darah tikus non diabetes. Hal ini dibuktikan dengan kadar aktivitas enzim SOD dan katalase pada serum darah tikus non diabetes yang diberi ekstrak umbi bawang dayak signifikan lebih tinggi dibandingkan dengan tikus non diabetes yang tidak diberi perlakuan. 
Tabel 2 Aktivitas SOD dan katalase serum, serta kadar MDA hati tikus percobaan

\begin{tabular}{|c|c|c|c|}
\hline Kelompok percobaaan & $\begin{array}{c}\text { MDA } \\
\left(\mathbf{n m o l ~ \mathbf { ~ m l } ^ { - 1 } )}\right.\end{array}$ & $\begin{array}{c}\text { Aktivitas SOD2 } \\
(\%)\end{array}$ & $\begin{array}{c}\text { Aktivitas } \\
\text { Katalase } \\
\left(\mathbf{U} \mathbf{~ m l}^{-1}\right)\end{array}$ \\
\hline Kontrol positif (KD) & $\begin{array}{l}160.27 \pm 19.33 \\
\mathrm{a}\end{array}$ & $\begin{array}{l}16.00 \pm 4.69 \\
b\end{array}$ & $179.75 \pm 3.59 \mathrm{c}$ \\
\hline Diabet, ekstrak air (DEA) & $\begin{array}{l}61.88 \pm 6.57 \\
b\end{array}$ & $\begin{array}{l}42.75 \pm 10.24 \\
a\end{array}$ & $195.00 \pm 2.83 \mathrm{a}$ \\
\hline $\begin{array}{l}\text { Diabet, ekstrak etanol } \\
\text { (DEE) }\end{array}$ & $\begin{array}{l}60.98 \pm 9.16 \\
b\end{array}$ & $\begin{array}{l}39.00 \pm 11.17 \\
\mathrm{a}\end{array}$ & $193.00 \pm 3.16 \mathrm{a}$ \\
\hline Kontrol obat (KO) & $\begin{array}{l}78.93 \pm 16.99 \\
b\end{array}$ & $\begin{array}{l}38.00 \pm 12.46 \\
\mathrm{a}\end{array}$ & $185.50 \pm 3.11 b$ \\
\hline Kontrol sehat (KS) & $\begin{array}{l}35.98 \pm 6.15 \\
c\end{array}$ & $\begin{array}{l}41.25 \pm 2.63 \\
a\end{array}$ & $195.75 \pm 2.06 \mathrm{a}$ \\
\hline Sehat, ekstrak air (SEA) & $\begin{array}{l}37.05 \pm 14.25 \\
\mathrm{c}\end{array}$ & $\begin{array}{l}46.25 \pm 10.66 \\
a\end{array}$ & $195.00 \pm 4.16 \mathrm{a}$ \\
\hline $\begin{array}{l}\text { Sehat, ekstrak etanol } \\
\text { (SEE) }\end{array}$ & $\begin{array}{l}64.11 \pm 15.34 \\
\mathrm{~b}\end{array}$ & $\begin{array}{l}40.50 \pm 8.70 \\
\mathrm{a}\end{array}$ & $195.25 \pm 0.96 \mathrm{a}$ \\
\hline
\end{tabular}

Rerata dengan notasi berbeda dalam kolom yang sama menunjukkan signifikansi pada taraf uji $5 \%$.

Tubuh memiliki enzim antioksidan alami yang bekerja mengatasi radikal bebas. Namun bila jumlah radikal bebas yang terbentuk sangat banyak sehingga melampau kemampuan enzim antioksidan untuk mengatasinya maka terjadilah stres oksidatif. Stres oksidatif, perubahan profil lipida dan gangguan metabolisme glukosa merupakan faktor risiko penting untuk diabetes, katarak (Shichi 2004), penyakit kardiovaskuler (Stocker dan Keaney 2004, Kumar et al. 2010), penuaan (Ben-Porath dan Weinberg 2005), dan kanker (Wijaratne et al. 2005). Defisiensi insulin pada diabetes melitus menyebabkan berbagai kekacauan dalam proses metabolisme dan regulasi yang pada gilirannya menyebabkan akumulasi lemak seperti kolesterol total pada pasien diabetes. Hal ini bisa terjadi karena kekurangan insulin menyebabkan peningkatan mobilisasi asam lemak bebas dari jaringan adiposa yang menghasilkan peningkatan produksi kolesterol LDL (Latha dan Daisy 2011). Dengan demikian salah satu komplikasi yang umum pada pasien diabetes adalah dislipidemia. Tingginya kolesterol total dan LDL kolesterol dalam darah merupakan faktor risiko utama penyakit koroner (Tchobroutsky 1978) dan menurut Wiztum (1991) oksidasi kolesterol LDL merupakan salah satu alasan utama terjadinya aterosklerosis pada manusia. Dengan demikian antioksidan berperan sangat penting dalam mencegah terjadinya komplikasi pada pasien diabetes melitus.

Pembuktian ilmiah terhadap kemampuan antihiperglikemik dan antihiperkolesterolemik ekstrak air dan ekstrak etanol umbi bawang dayak telah dilaporkan oleh Febrinda et al. (2014) yang menyatakan bahwa tikus diabetes yang diberi ekstrak air dan ekstrak etanol umbi bawang dayak dengan dosis $100 \mathrm{mg} / \mathrm{kg}$ bb secara oral selama 28 hari memperlihatkan kadar glukoso darah, kadar kolesterol total, dan kadar kolesterol LDL signifikan lebih rendah dibandingkan dengan kelompok tikus diabetes yang tidak diberikan perlakuan. Di dalam studi tersebut juga disebutkan kadar insulin serum tikus diabetes yang diberi perlakuan ekstrak bawang dayak signifikan lebih tinggi dibandingkan dengan kelompok tikus diabetes yang tidak diberi perlakuan.

Eleutherine palmifolia termasuk ke dalam famili Iridaceae. Spesies dari famili Iris (Iridaceae) telah memiliki sejarah yang panjang dalam pengobatan tradisinal di dunia, dan sejak dahulu telah diketahui memiliki banyak kandungan metabolit sekuder terutama 
flavonoid (Wang et al. 2010). Kemampunan pemutusan reaksi berantai radikal oleh flavonoid tterutama karana kehadiran setidaknya dua kelompok o-hidroksil pada cincin B. (Majewska et al. 2011). Menurut Grace-Lynn et al. (2012) selain Senyawa fenol dan polifenol, Senyawa triterpenoid juga diketahui memiliki aktivitas antioksidan yang tinggi. Kemampuan antioksidan umbi bawang dayak tidak terlepas dari kandungan senyawa golongan alkaloid, tannin, fenolik, flavonoid dan triterpenoid yang terkandung di dalam ekstrak air dan ekstrak etanol umbi bawang dayak (Febrinda et al. 2013).

\section{KESIMPULAN DAN SARAN}

\section{Kesimpulan}

Pemberian ekstrak air dan etanol umbi bawang dayak selama 28 hari pada tikus diabetes memperlihatkan aktivitas antioksidan yang dimiliki oleh ekstrak tanaman tersebut yang dibuktikan dengan kadar malonaldehid (MDA) pada jaringan hati signifikan lebih rendah dibandingkan dengan yang terdapat pada kelompok tikus kontrol. Kapasitas antioksidan yang dimiliki oleh ekstrak tersebut juga berhasil menghemat pemakaian antioksidan alami tubuh yang dibuktikan dengan aktivitas enzim SOD dan enzim katalase pada serum tikus diabetes yang mendapatkan perlakuan pemberian ekstrak bawang dayak signifikan lebih tinggi dibandingkan dengan yang terdapat pada kelompok tikus kontrol. Kemampuan antioksidan, antihiperglikemik, dan antikolesterolemik yang dimiliki ekstrak air dan ekstrak etanol umbi bawang dayak merupakan petunjuk bahwa tanaman tersebut memiliki potensi untuk mencegah terjadinya komplikasi vaskuler pada penderita diabetes melitus.

\section{Ucapan Terima Kasih}

Penelitian ini didanai oleh Doctorate Research Fund tahun 2012 dari Danone Institute Indonesia.

\section{DAFTAR PUSTAKA}

[AOAC] Association of Analytical Communities. 2005. Official Methods of Analysis. Washington DC.

Bell DS. 1994. Stroke in the diabetic patient. Diabetes Care. 17: 213-219

Ben Porath I, Weinberg RA. 2005. The signals and pathways activating cellular senescence. Int J Biochem Cell. B37:961-976.

Etuk EU. 2010. Animals models for studying diabetes mellitus. Agric. Biol. J.N.Am. 1: 130-134.

Febrinda AE, Astawan M, Wresdiyati T, Yuliana ND. Kapasitas antioksidan dan inhibitor alfa glukosidase ekstrak umbi bawang dayak. J Teknol dan Industri Pangan 24(2):161-167.

Febrinda AE, Yuliana ND, Ridwan E, Wresdiyati T, and Astawan M. 2014. Hyperglycemic control and diabetes complication preventive activities of Bawang Dayak (Eleutherine palmifolia L. Merr.) bulbs extracts in alloxan diabetic rats. IFRJ 21(4):1405-1411.

Galingging YR. 2009. Bawang Dayak (Eleutherine palmifolia) sebagai tanaman obat multi fungsi. Warta Penelitian dan Pengembangan.[Internet]. [diunduh 2011 Juli 21]; 15(3). Tersedia pada www.kalteng.litbang.deptan.go.id. 
Grace-Lynn C, Darah I, Chen Ym Latha LY, Jothy SL, Sasidharan S. 2012. In vitro antioxidant activity potential of lantadene A, a pentacyclic triterpenoid of lantana plants. Molecules 17(9):11185-98.

Kumar BSA, Lakhsman K, Jayaveea KN, Shekar DS, Khan S, Thippeswamy BS, Veerapur VP, 2010. Antidiabetic, antihyperlipidemic and antioxidant activities of methanolic extract of Amaranthus viridis Linn in alloxan induced diabetic rats. Exp Toxicol Pathol. Doi:10.1016/j.etp2010.06.009.

Latha RCR, Daisy P. 2011. Insulin secretagogue, antihyperlipidemic and other protective effects of gallic acid isolated from Terminalia bellerica Roxb. in streptozotocininduced diabetic rats. Chem. Biol. Interact. 189: 112-118.

Majewska M, Skrzyck M, Podsiad M, Czecszot H. 2011. Evaluation of antioxidant potential of flavonoids: an in vitro study. Acta Pol Pharm. 68:611-615.

[NRC] National Research Council. 2011. Guide for The Care and Use of Laboratory Animals. $8^{\text {th }}$ ed. The National Academic Press. Washington DC. 246 p.

Sa'roni P, Nurendah, Adjirni. 1987. Penelitian efek anti inflamasi beberapa tanaman obat pada tikus putih. Kongres Biologi Nasional VIII. Purwokerto, 8-10 Oktober.

Saptowalyono CA. 2007. Bawang Dayak, Tanaman Obat Kanker Yang Belum Tergarap. [Internet]. [diunduh 2011 Mei 25]. Tersedia pada www.kompas.com.

Singh RP, Murthy KNC, Jayaprakasha GK. 2002. Studies on the antioxidant activity of pomegranate (Punica granatum) peel and seed extracts using in vitro models. $J$. Agric. Food Chem. 50: 81-86.

Sinha AK. 1972. Colorimetric assay of catalase. Anal. Biochem. 47: 389-394.

Shichi H. 2004. Cataract formation and prevention. Expert Opin Inv Drug. 13:691-701.

Stocker and Keaney. 2004. Role of oxidative modifications in atherosclerosis. Physiol Rev. $84: 1381-1478$.

Tchobroutsky G. 1978. Relation of diabetic control to development of micro vascular complication. Diabetologia. 15: 143-152.

Wang H, Cui Y, Zhao C. 2010. Flavonoids of the genus Iris (Iridaceae). Mini-Rev Med Chem. 10:63

Wijeratne SSK, Cuppett SL, Schlegel V. 2005. Hydrogen peroxide induce oxidative stress damage and antioxidant enzyme response in caco-2 human colon cells. J. Agric. Food. Chem. 53: 8768-8774.

Wiztum JL, Steinberg D. 1991. Role of oxidized low density lipoprotein in atherogenesis. J. Clin. Invest. 88: 1785-1792. 